\title{
The effects of growth medium and partial shade on early growth of milkweed (Calotropis procera L.) under drought stress
}

\author{
Mansour Taghvaei* and Mojtaba Dolat Kordestani \\ Department of Desert Region Management, College of Agriculture, Shiraz University, Shiraz 7144165186, Iran
}

\begin{abstract}
The use of growth medium is often recommended milkweed seedlings to grow and develop after emergence, and it is affected by growth medium and local habitat conditions. The effects of growth medium and partial shade on early growth of milkweed under drought stress (Calotropis procera L.) were studied in a field experiment. A split-split plot experimental design with three replications was carried out in the nursery. The main treatment plot was divided into two levels of shade; (no shading and partial shading). Sub treatment plot1 included growth medium at four levels (G1 = clay [suitable for milkweed growth], G2 = clay + sand, G3 = clay + perlite, G4 = clay + perlite + sand) and sub treatment plot2 included drought (irrigation intervals) at six levels ( $\mathrm{D} 1=2$ [control], $\mathrm{D} 2=4, \mathrm{D} 3=6, \mathrm{D} 4=8, \mathrm{D} 5=10$, and $\mathrm{D} 6=12$ days per for three month). The results showed that drought stress significantly decreased emergence percentage, shoot length, shoot dry weight (SDW1), root dry weight (RDW), seedling dry weight (SDW2) and vigor index (VI). The use of growth medium increased all seedling characteristics. The G3 (clay + perlite) growth medium showed the highest performance, especially in terms of emergence percentage and seedling dry weight. Partial shade improved shoot length, shoot dry weight, and vigor index. Our results showed that the best treatment for high-vigor milkweed seedlings under drought stress was G3 (clay + perlite) growth medium and partial shade.
\end{abstract}

Key words: Calotropis procera L., drought stress, early vigor, emergence percentage, growth medium, partial shade

\section{INTRODUCTION}

Approximately $60 \%$ of Iran is classified as arid and semi-arid land. Much of the country has a desert climate with an average annual precipitation of less than $300 \mathrm{~mm}$ (Mansoory 1992). Sadeghian et al. (2010) reported that milkweed (Calotropis procera L.) can adapt to arid land. This species is one of the most important deciduous tree desert species in south Iran. It is very apparent that the effects of human activities and livestock on dry land have severely limited tree growth in some regions. Cutting and grazing has drastically reduced the extent of many forests throughout the country, and sufficient consid- eration of plant's success rate, especially seedling vigor, must be made prior to re-planting efforts (El-Moslimany 1986). Calotropis sp. produces lots of small seeds which are dispersed by wind, but has a low density per unit area because its germination stage is sensitive to drought (Bazrafkan 2011). Seed germination performs an important function in the regeneration of plant species, particularly under arid and unpredictable environmental conditions, most notably those of Mediterranean ecosystems (Giménez-Benavides et al. 2005). Low seedling vigor, especially poor emergence and seedling establishment are regarded

\section{Open Access http://dx.doi.org/10.5141/JEFB.2012.040}

This is an Open Access article distributed under the terms of the Creative Commons Attribution Non-Commercial License (http://creativecommons. org/licenses/by-nc/3.0/) which permits unrestricted non-commercial use distribution, and reproduction in any medium, provided the original work is properly cited.
Received 25 July 2012, Accepted 19 October 2012

*Corresponding Author

E-mail: taghvaei@shirazu.ac.ir Tel: +98-711-613-8163 
as major causes of these low densities (Close and Wilson 2002). Seed emergence, seedling establishment and survival are affected by light, climate and edaphic and species-specific factors (Bewley and Black 1994). Thus, any study of dry land restoration should ideally separate the effects of individual environmental factors and their interactions on demographic stages. In dry lands, emergence, seedling growth and survival are affected by light intensity (Khurana and Singh 2001). The reflex of emergence to light intensity depends on the individual species as well as the environment. Biomass production, relative growth rate, root/shoot ratio, specific leaf area, net assimilation rate, and leaf area ratio can be limited by either poor light availability (Rincón and Huante 1993) or low soil moisture, due to the removal of water from the dry forest understory by nurse trees (Rodríguez-Calcerrada et al. 2008). Partial shade protects soil moisture during seed emergence in dry forests. In dry lands, species emergence and early establishment must occur during the beginning of wet season when water is most plentiful (Khurana and Singh 2001). In dry lands, most precipitation occurs in winter and spring (Ginley 2008). When temperature rises quickly, water evaporates and rainfall may be extremely scarce during summer. Emergence can also be affected by water content of the growth medium. Soil water storage capacity depends on soil tissue and type. These characteristics positively affect the establishment of different plant species (Grange and Loach 1983, Newton et al. 1992). Perlite materials absorb water, and prevent the penetration of too much water to the lower layers of soil. Damizadeh (2004) used perlite as a growth medium for Capparis decidua. Yusef Saleh (2011) reported that sand mixed with perlite is the best growth medium for vegetative growth of Dahlia (Dahlia pinnata), Marigold (Tagetes erecta), Zinnia (Zinnia elegans) and Cosmos (Cosmos bipinnatus) plants. Abo-Rezq et al. (2009) used sand in growth media on selected plant species To facilitate the emergence. The general hypothesis of this study is that the combination of environmental factors and partial shade affects the early stages of the life cycle of a milkweed seed. This study aims to study the effects of growth medium and partial shade on early vigor of (Calotropis procera L.) under drought stress in mid-spring.

\section{MATERIALS AND METHODS}

\section{Plant material}

Mature seeds of milkweed (Calotropis procera L.) were collected from natural populations in the desert area in Sistan Balochestans province $\left(60^{\circ} \mathrm{N}\right.$ and $\left.29^{\circ} \mathrm{E}\right)$, located in the elevations of 1,396 $\mathrm{m}$ above mean sea level (AMSL) in Southeast desert of Iran, and were stored in bags in a refrigerator $\left(5^{\circ} \mathrm{C}\right)$ until the start of the experiment.

\section{Experimental design}

The split-split plot experimental design with three replications was carried out in a nursery. The main treatment plot was divided into two shade treatments (no shading and partial shading) and sub treatment plotl included growth medium at four levels ( $\mathrm{Gl}=$ clay [the soil type in the milkweed growth region], G2 = clay + sand, G3 = clay + perlite, G4 = clay + perlite + sand), and sub treatment plot 2 included drought (irrigation interval) at six levels (D1 = 2 [control], D2 = 4, D3 = 6, D4 = 8, D5 = per 10 and D6 = 12 days per for three month). Ten seeds were planted in each treatment area in a 1 liter plastic pot filled with the various soil type. The pots were watered according to the irrigation treatments. Vigor-related traits were the measured for the individual plants after two months. The traits were: emergence percentage, shoot length, root length, shoot dry weight, root dry weight, seedling dry weight and vigor index. Shoot and root dry weights were measured after drying for $24 \mathrm{~h}$ in an oven at $70^{\circ} \mathrm{C}$ (ISTA 2002). Vigor index was calculated for each treatment as follows (Abdul-Baki and Anderson 1973):

Vigor index $=$ seedling length $\times$ emergence percentage

\section{Data analyses}

Data were checked for normality and were then analyzed using SAS ver. 9.1.3 (SAS Institue Inc., Cary, NC, USA). Treatment means were separated by Duncan's multiple range test if the $F$-value of the treatments was significant at the 0.05 or 0.01 probability levels.

\section{RESULTS}

\section{Emergence percentage}

Drought stress and soil treatments had significant $(P$ $<0.01$ ) effects on emergence percentage (Table 1). The highest and lowest emergence percentage was obtained in D1 (control) and D6 irrigation interval respectively. The emergence percentage of $C$. procera $\mathrm{L}$. decreased with increasing the irrigation intervals, with $96.25 \%$ emergence 
Table 1. Analysis of variance for seedling parameters

\begin{tabular}{|c|c|c|c|c|c|c|c|c|}
\hline $\begin{array}{l}\text { Changes in } \\
\text { resources }\end{array}$ & $\begin{array}{l}\text { Degrees of } \\
\text { freedom }\end{array}$ & $\underset{(\%)}{\text { Emergence }}$ & $\begin{array}{l}\text { Root length } \\
\text { (cm) }\end{array}$ & $\begin{array}{c}\text { Shoot } \\
\text { length }(\mathrm{cm})\end{array}$ & $\begin{array}{c}\text { Root dry } \\
\text { weight (g) }\end{array}$ & $\begin{array}{l}\text { Shoot dry } \\
\text { weight (g) }\end{array}$ & $\begin{array}{l}\text { Seedling dry } \\
\text { weight (g) }\end{array}$ & $\begin{array}{l}\text { Vigor } \\
\text { index }\end{array}$ \\
\hline Drought (D) & 5 & $1,544.44^{* *}$ & $67.9^{* *}$ & $62.75^{* *}$ & $0.64^{* *}$ & $0.56^{* *}$ & $1.36^{* *}$ & $881,939.28^{* *}$ \\
\hline Growth medium (G) & 3 & $950^{* *}$ & $24.82^{* *}$ & $8.42^{* *}$ & $0.22^{* *}$ & $0.1^{* *}$ & $0.56^{* *}$ & $463,667.87^{* *}$ \\
\hline Light (L) & 1 & $1,002.77^{* *}$ & $82.71^{* *}$ & $804.02^{* *}$ & $0.23^{* *}$ & $3.07^{* *}$ & $1.61^{* *}$ & $4,382,485.4^{* *}$ \\
\hline $\mathrm{D} \times \mathrm{G}$ & 15 & $71.11^{\mathrm{ns}}$ & $0.07^{\mathrm{ns}}$ & $0.07^{\mathrm{ns}}$ & $0.22^{* *}$ & $0.05^{* *}$ & $0.22^{* *}$ & $15,083.03^{\mathrm{ns}}$ \\
\hline $\mathrm{D} \times \mathrm{L}$ & 5 & $56.11^{\mathrm{ns}}$ & $0.1^{\mathrm{ns}}$ & $0.84^{* *}$ & $0.05^{*}$ & $0.6^{* *}$ & $1.02^{* *}$ & $25,552.32^{\mathrm{ns}}$ \\
\hline $\mathrm{G} \times \mathrm{L}$ & 3 & $75^{\mathrm{ns}}$ & $3.16^{* *}$ & $1.02^{* *}$ & $0.02^{\mathrm{ns}}$ & $0.009^{\mathrm{ns}}$ & $0.01^{\mathrm{ns}}$ & $56,147.99^{*}$ \\
\hline $\mathrm{D} \times \mathrm{G} \times \mathrm{L}$ & 15 & $21^{\mathrm{ns}}$ & $0.09^{\mathrm{ns}}$ & $0.18^{* *}$ & $0.1^{* *}$ & $0.08^{\mathrm{ns}}$ & $0.25^{* *}$ & $5,825.44^{\mathrm{ns}}$ \\
\hline Error & 96 & 59.72 & 0.27 & 0.07 & 0.02 & 0.01 & 0.04 & $11,690.54$ \\
\hline $\mathrm{CV} \%$ & & 13.77 & 21.67 & 12.07 & 23.45 & 18.82 & 23.63 & 11.32 \\
\hline
\end{tabular}

${ }^{*},{ }^{* *}$ and ns indicate significant at $P<0.05, P<0.01$ and not significant, respectively.

Table 2. Effects of drought stress, growth medium and partial shade on mean seedling parameters

\begin{tabular}{lllll}
\hline & $\begin{array}{c}\text { Emergence } \\
(\%)\end{array}$ & $\begin{array}{c}\text { Root } \\
\text { length } \\
(\mathbf{c m})\end{array}$ & $\begin{array}{c}\text { Shoot } \\
\text { length } \\
(\mathbf{c m})\end{array}$ & $\begin{array}{c}\text { Vigor } \\
\text { index } \\
(\mathbf{c m})\end{array}$ \\
\hline Drought stress & & & & \\
D1 (control) & $96.25^{\mathrm{a}}$ & $13.75^{\mathrm{d}}$ & & $1,462.31^{\mathrm{a}}$ \\
D2 & $90^{\mathrm{b}}$ & $14.61^{\mathrm{c}}$ & & $1,308.88^{\mathrm{b}}$ \\
D3 & $82.91^{\mathrm{c}}$ & $15.51^{\mathrm{b}}$ & & $1,145.08^{\mathrm{c}}$ \\
D4 & $74.58^{\mathrm{d}}$ & $16.48^{\mathrm{a}}$ & & $952.29^{\mathrm{e}}$ \\
D5 & $71.33^{\mathrm{d}}$ & $12.53^{\mathrm{e}}$ & & $1,053.04^{\mathrm{d}}$ \\
D6 & $70.45^{\mathrm{d}}$ & $12.18^{\mathrm{f}}$ & & $1,036^{\mathrm{d}}$ \\
Growth medium & & & & \\
G1 (control) & $82.77^{\mathrm{c}}$ & $13.1^{\mathrm{d}}$ & 12.7 & $1,047.32^{\mathrm{c}}$ \\
G2 & $85.27^{\mathrm{c}}$ & $14.08^{\mathrm{c}}$ & 13.04 & $1,095.02^{\mathrm{c}}$ \\
G3 & $94.44^{\mathrm{a}}$ & $15.08^{\mathrm{a}}$ & 13.83 & $1,303.81^{\mathrm{a}}$ \\
G4 & $89.72^{\mathrm{b}}$ & $14.44^{\mathrm{b}}$ & 13.32 & $1,192.25^{\mathrm{b}}$ \\
Light condition & & & & \\
Light & $90.69^{\mathrm{a}}$ & $14.94^{\mathrm{a}}$ & $985.15^{\mathrm{b}}$ & \\
Partial shade & $85.41^{\mathrm{b}}$ & $13.42^{\mathrm{b}}$ & $1,334.05^{\mathrm{a}}$ & \\
\hline
\end{tabular}

Means with the same letter on each column are not significantly different $(P<0.05)$. in D1 (control) and 70.45\% emergence in D6 irrigation interval treatment (Table 2). The growth medium had significant $(P<0.01)$ effects on emergence percentages, as $82.77 \%$ emerged in G1 (control) and $94.44 \%$ emerged in G3 (clay + perlite) (Table 2). Emergence percentage was significantly $(P<0.01)$ affected by light treatments also (Table 1). Partial shade treatment decreased the emergence percentage in all growth medium and irrigation treatments. The mean emergence percentages were $90.69 \%$ and $85.41 \%$ in light and partial shade, respectively (Table 2).

\section{Shoot and root length}

Shoot and root length were significantly $(P<0.01)$ affected by the interaction of growth medium and light (Table 1). For example, root length changed from $14.28 \mathrm{~cm}$ in G1 (control) to $15.69 \mathrm{~cm}$ in G3 under light treatment. Also, it changed from $11.91 \mathrm{~cm}$ in Gl (control) to $14.47 \mathrm{~cm}$ in G3 under partial shade treatment (Table 3). In other words, root length increased by $1.41 \mathrm{~cm}(8.9 \%)$ and 2.26

Table 3. Effect of growth medium and partial shade on the average of seedling parameters

\begin{tabular}{|c|c|c|c|c|c|}
\hline & G1 (control) & G2 & G3 & G4 & \\
\hline \multicolumn{6}{|l|}{ Root length (cm) } \\
\hline Light & $14.28^{\mathrm{bc}}$ & $14.79^{\mathrm{ab}}$ & $15.69^{\mathrm{a}}$ & $14.97^{\mathrm{ab}}$ & $14.94^{\mathrm{a}}$ \\
\hline \multirow[t]{2}{*}{ Partial shade } & $11.91^{\mathrm{d}}$ & $13.38^{\mathrm{c}}$ & $14.47^{\mathrm{bc}}$ & $13.92^{\mathrm{bc}}$ & $13.42^{\mathrm{b}}$ \\
\hline & $13.1^{\mathrm{d}}$ & $14.08^{\mathrm{c}}$ & $15.08^{\mathrm{a}}$ & $14.44^{\mathrm{b}}$ & \\
\hline \multicolumn{6}{|l|}{ Shoot length (cm) } \\
\hline No partial shade & 10.34 & 10.69 & 11.24 & 10.99 & 10.84 \\
\hline \multirow[t]{2}{*}{ Partial shade } & 15.07 & 15.4 & 16.41 & 15.65 & 15.63 \\
\hline & 12.7 & 13.09 & 13.82 & 13.32 & \\
\hline \multicolumn{6}{|l|}{ Vigor index (VI) } \\
\hline Light & $872.7^{\mathrm{e}}$ & $969.22^{\mathrm{de}}$ & $1,081.28^{\mathrm{cd}}$ & $1,017.39^{\mathrm{de}}$ & $985.15^{\mathrm{b}}$ \\
\hline \multirow[t]{2}{*}{ Partial shade } & $1,221.94^{\mathrm{c}}$ & $1,220.82^{c}$ & $1,526.34^{\mathrm{a}}$ & $1,367.11^{\mathrm{b}}$ & $1,334.05^{\mathrm{a}}$ \\
\hline & $1,047.32^{\mathrm{c}}$ & $1,095.02^{\mathrm{c}}$ & $1,303.81^{\mathrm{a}}$ & $1,192.25^{\mathrm{b}}$ & \\
\hline
\end{tabular}

Means with the same letter on each column are not significantly different $(P<0.05)$. 
cm (15.6\%) under light and partial shade treatments, respectively (Table 3). Shoot length was increased from $10.34 \mathrm{~cm}$ in G1 (control) to $11.24 \mathrm{~cm}$ under G3 light treatment. Moreover, it increased from $15.07 \mathrm{~cm}$ in G1 (control) to $16.41 \mathrm{~cm}$ under G3 partial shade treatment (Table 3). In other words, root length increased $0.09 \mathrm{~cm}$ and 1.34 $\mathrm{cm}$ under light and partial shade treatments, respectively (Table 3). Interaction of drought stress and light treatments had significant $(P<0.01)$ effects on shoot length (Table 1). Shoot length decreased with increasing drought stress in light and partial shade. The shoot length changed from $12.67 \mathrm{~cm}$ in D1 (control) to $9.16 \mathrm{~cm}$ in D4 under light treatment. Also, it changed from $17.57 \mathrm{~cm}$ in D1 (control) to $13.23 \mathrm{~cm}$ in D4 under partial shade (Table 4).

\section{Shoot and root dry weight}

Interaction of drought stress with growth medium as well as drought stress with light had significant $(P<0.01)$ effects on root and shoot dry weight (Table 1). Growth medium decreased drought stress effects on root and shoot dry weight more effectively under light treatments. Root and shoot dry weight changed from $0.64 \mathrm{~g}$ and $0.11 \mathrm{~g}$ to $0.97 \mathrm{~g}$ and $0.14 \mathrm{~g}$ in D1 and G3, respectively. Additionally, root and shoot dry weight changed from $0.08 \mathrm{~g}$ and $0.04 \mathrm{~g}$ to $0.23 \mathrm{~g}$ and $0.08 \mathrm{~g}$ in D6 and G3, respectively (Table 4). Growth medium decreased the effects of drought stress on root and shoot dry weight under the partial shade

Table 4. Interaction of growth medium, drought stress levels and partial shade on average of seedling parameter

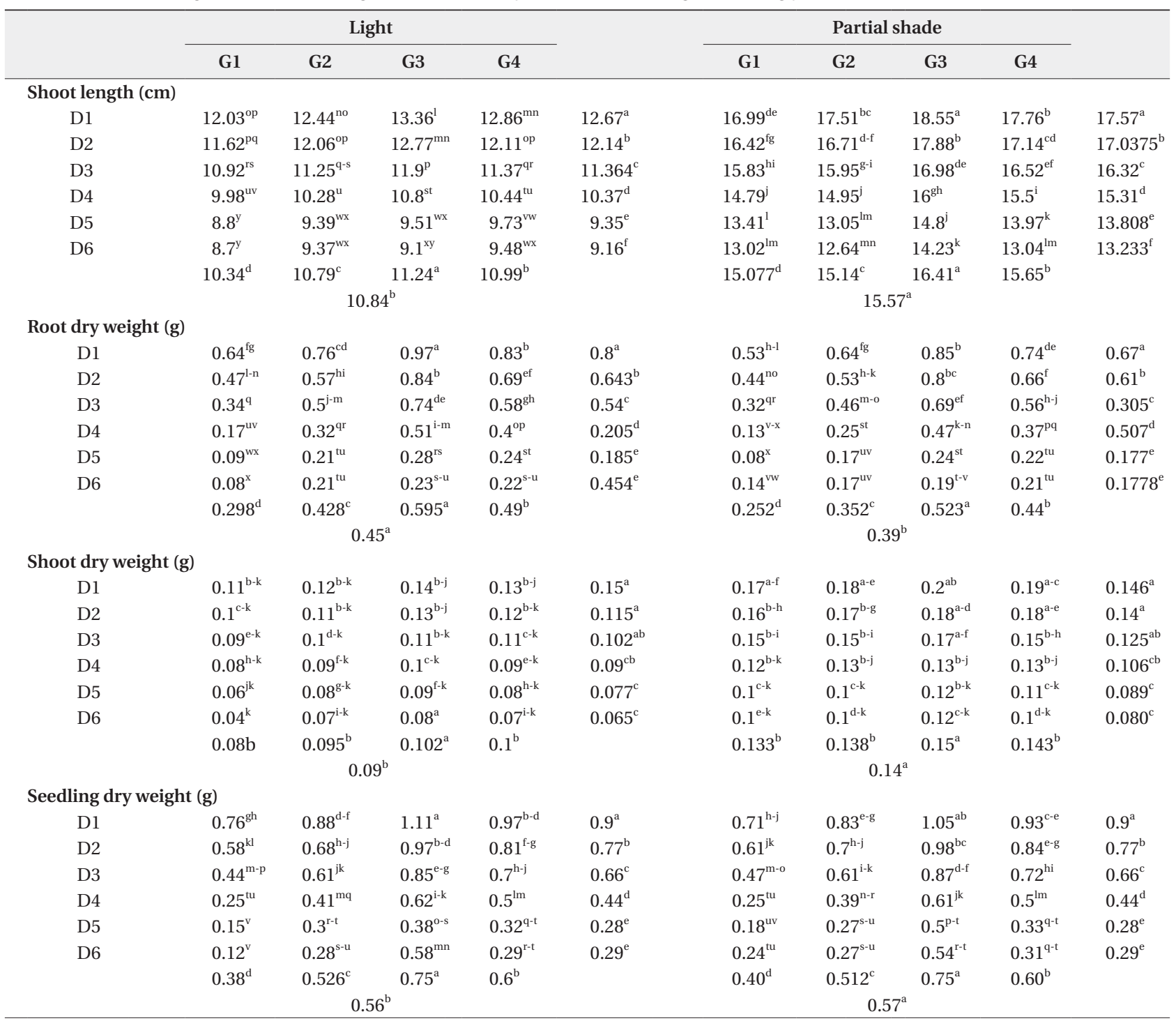

Means with the same letter on each column are not significantly different $(P<0.05)$. 
treatment. Root and shoot dry weight were increased from $0.53 \mathrm{~g}$ and $0.17 \mathrm{~g}$ in D1 and G1 to $0.85 \mathrm{~g}$ and $0.2 \mathrm{~g}$ in D1 and G3. Also, root and shoot dry weight changed from $0.14 \mathrm{~g}$ and $0.1 \mathrm{~g}$ in D6 and $\mathrm{G} 1$ to $0.19 \mathrm{~g}$ and $0.12 \mathrm{~g}$ in D6 and G3 (Table 4).

\section{Seedling dry weight}

Seedling dry weight was significantly $(P<0.01)$ affected by the interaction of drought stress with growth medium treatments (Table 1). Seedling dry weight decreased with the increase of drought stress, as the seedling dry weight changed from $0.76 \mathrm{~g}$ in $\mathrm{Gl}$, D1(control) to $0.12 \mathrm{~g}$ in G1, D6 (Table 4). Growth medium decreased the effects of drought stress, as seedling dry weight changed from 0.76 $\mathrm{g}$ in G1, D1 to $0.12 \mathrm{~g}$ in G1, D6. Seedling dry weight was $1.11 \mathrm{~g}$ in G3, D1 and $0.58 \mathrm{~g}$ in G3, D6 (Table 4). Seedling dry weight was significantly $(P<0.01)$ affected by the interaction of drought stress with light treatments (Table 1). Partial shade decreased the effects of drought stress. While seedling dry weight was $1.11 \mathrm{~g}$ in G3, D1 and $0.58 \mathrm{~g}$ in G3 D6 under light treatment, it was $1.05 \mathrm{~g}$ in G3, D1 and $0.4 \mathrm{~g}$ in G3, D6 under partial shade treatment (Table 4).

\section{Vigor index}

Vigor index was significantly $(P<0.01)$ affected by drought stress (Table 1). Vigor index decreased with increasing drought stress, as it was 1,462.31 in D1 (control) but just 1,036 in D6 (Table 2). Growth medium increased the vigor index from 1,047.32 in G1 to 1303.81 in G3 (Table 2).

There was significant $(P<0.01)$ difference in the vigor index between light treatments (Table1). Partial shade increased the vigor index, which was calculated to be 985.15 and 1,334.05 in no shade and partial shade respectively (Table 2).

\section{DISCUSSION}

The results show that Calotropis procrea L. is sensitive to drought stress in the emergence stage. Drought stress was found to reduce emergence percentage, shoot and root length (Table 2), as well as shoot, root and seedling dry weight (Table 3). Bazrafkan (2011) reported that Calotropis procrea $\mathrm{L}$. is sensitive to drought in the germination stage. Ghaedi et al. (2009) reported that seeds of Haloxylon aphyllum $\mathrm{L}$. as a halophyte is sensitive to drought and salinity in germination stage. Ramazani et al. (2009) report- ed similar findings about (Capparis spinosa L.). Similar findings have also been reported for Atriplex griffithii var. stoksii (Khan and Rizvi 1994), Kalidium capsicum (Tobe et al. 2000), Calotropis procera L (Taghvaei et al. 2012). Drought stress decreases soil osmotic potential, which in turn, decreases the water uptake of seeds, thereby inhibiting their emergence (Katembe et al. 1998). Emergence percentage, shoot length and root length were significantly affected by light treatments (Table 1). Duchesne et al. (2000) reported the positive effect of partial shade on the early establishment of eastern white pine seedlings. Taghvaei (2010) reported that partial shade treatments had significant effects on emergence percentages and rates, shoot length, shoot dry weight, root dry weight, leaf area, and Chlorophyll content of Quercus brantii L. Partial shade could increase shoot length (Qian and Engelke 1999). Ray and Brown (1995) reported that emergence success in dry forest in the US Virgin Islands was approximately equal under conditions of partial- and no-shade. Growth medium had positive effects on all characteristics of $C$. procera $\mathrm{L}$. seedlings. The results showed that emergence percentage, shoot and root length, vigor index, as well as shoot and root dry weight increased with the application of lighter-textured soil (Table 2). Similar results were reported for Salsola vermiculata (Guma and Padrón-Mederos et al. 2010). Damizadeh (2004) reported that light textured sandy and sandy loam is the most appropriate growth medium for Capparis decidua seedling survival. It seems that it has positive effects on ventilation and drainage. Abo-Rezq et al. (2009) found out that a mixture of perlite with peatmoss and sand is the best growing medium for Chlorophytum comcosum and Lycopersicom esculentum $\mathrm{cv}$. Using sand improves the physical properties of a growing media and improves drainage (Wilson and Stoffella 2006).

\section{CONCLUSION}

Calotropis sp. is a species adapted to the deserts of southern Iran (Sadeghian et al. 2010). Calotropis sp. is sensitive to drought (Bazrafkan 2011) and salinity (Taghvaei et al. 2012). Climate change has increased periods of drought innmany regions of Iran, and additional anthropogenic influences, including farming practices, have reduced the density of Calotropis sp. in these areas, even though many seeds are produced. In Calotropis sp., root initiation and growth ceased at soil osmotic potentials between -0.4 and -0.6 MPa (Bazafkan 2011). Under these dry conditions, the germination and early establishment 
of many species, especially Calotropis sp., must occur during the wet season or at the end of winter, when water is more available. Evaporation from the top layer of soil in early spring decreases germination of species seeds. Partial shade is modified at the ground level with a reduction of temperature (Rincón and Huante 1993). Partial shade treatment seems to result in sufficient alteration of the microclimate for a significant improvement in emergence and establishment (Gehlhausen et al. 2000). In this experiment, partial shade treatment was found to have an influence on seedling emergence and seedling growth. Partial shade treatment increased shoot length and vigor index, but decreased emergence percentage. Partial shade protect soil moisture, and improves the field emergence of seeds (Chalton et al. 1986). Consequently, light quality becomes a limiting factor for their survival and growth (Crow 1988). Although low light as a dominant environmental factor limits seedling establishment under partial shade treatment, it may increase root growth. Root regeneration and root growth are very sensitive to soil moisture stress (López-Barrera and Newton 2005). So, to increase germination, the growth medium which will retain rain water for a longer time must be considered. Sand+perlite media increased root characteristics, and this may imply that this medium had better water retention properties. The use of perlite allows plants to optimize water and oxygen holding, and could affect plant growth and the development of roots and shoots directly or indirectly, as perlite increases aeration and water holding capacity of soil (Leakey et al. 1990, Ofori et al. 1996). Therefore, to improve the establishment of milkweed in dry semi-arid regions, it is suggested that seeds be planted under a canopy of native plants as nurse plant. Because organic matter is derived from litter under the canopy of these plants, rain water will be retained with greater efficiency, thus improving germination and emergence percentages. The partial shade of nurse plants result in the improvement of the microclimate, which can be sufficient to maintain young seedlings against a variety of effects, including excess radiation and grazing in arid and semi-arid lands.

\section{LITERATURE CITED}

Abdul-Baki AA, Anderson JD. 1973. Vigor determination in soybean seed by multiple criteria. Crop Sci 13: 630-633.

Abo-Rezq H, Albaho M, Thomas B. 2009. Effect of sand in growing media on selected plant species. Eur J Sci Res 26: 618-623.

Bazrafkan M. 2011. Influence of drought stress on germi- nation of Calotropis procera L. and improvement of threshold. MSc Thesis. Shiraz University, Faculty of Agriculture, Shiraz, Iran. (in Persian)

Bewley JD, Black M. 1994. Seeds: Physiology of Development and Germination. Plenum Press, New York and London.

Chalton JF, Hampton JG, Scott DJ. 1986. Temperature effects on germination of New Zealand herbage grasses. Proc $\mathrm{N}$ Z Grassl Assoc 47: 165-172.

Close DC, Wilson SJ. 2002. Provenance effects on pre-germination treatments for Eucalyptus regnans and E. delegatensis seed. For Ecol Manag 170: 299-305.

Crow TR. 1988. Reproductive mode and mechanisms for self-replacement of northern red oak (Quercus rubra): a review. For Sci 34: 19-40.

Damizadeh GR. 2004. Effect of environmental conditions on survival of Capparis decidua seedling. Iran J For Poplar Res 12: 509-531.

Duchesne LC, Herr DG, Wetzel S, Thompson ID, Reader R. 2000. Effect of seed predation, shade and soil organic matter on the early establishment of eastern white pine and balsam fir seedlings. For Chron 76: 759-763.

El-Moslimany AP. 1986. Ecology and late-Quaternary history of the Kurdo-Zagrosian oak forest near Lake Zeribar, western Iran. Vegetatio 68: 55-63.

Gehlhausen SM, Schwartz MW, Augspurger CK. 2000. Vegetation and microclimatic edge effects in two mixedmesophytic forest fragments. Plant Ecol 147: 21-35.

Ghaedi M, Taghvaei M, Fallah Shamsi SR, Niazi A. 2009. The influence of light, temperature and salinity on seed germination of Haloxylon aphyllum L. Sci Res J Iran Range Manag Soc 2: 411-420.

Giménez-Benavides L, Escudero A, Pérez-García F. 2005. Seed germination of high mountain Mediterranean species: altitudinal, interpopulation and interannual variability. Ecol Res 20: 433-444.

Ginley MM. 2008. Conservation Biology, Ecology and Biolodiversity. Zagros Mountains Forest Steppe. Encyclopedia of Earth.

Grange RI, Loach K. 1983. The water economy of unrooted leafy cuttings. J Hortic Sci 58: 1-17.

Guma IR, Padrón-Mederos MA, Santos-Guerra A, ReyesBetancort JA. 2010. Effect of temperature and salinity on germination of Salsola vermiculata L. (Chenopodiaceae) from Canary Islands. J Arid Environ 74: 708-711.

ISTA. 2002. International rules of seed testing. Seed Sci Technol 20: 53-55.

Katembe WJ, Ungar IA, Mitchell JP. 1998. Effect of salinity on germination and seedling growth of two Atriplex species (Chenopodiaceae). Ann Bot 82: 167-175.

Khan MA, Rizvi Y. 1994. Effect of salinity, temperature, and 
growth regulators on the germination and early seedling growth of Atriplex griffithii var. stoksii. Can J Bot 72: 475479.

Khurana E, Singh JS. 2001. Ecology of seed and seedling growth for conservation and restoration of tropical dry forest: a review. Environ Conserv 28: 39-52.

Leakey RRB, Mesén JF, Tchoundjeu Z, Longman KA, Dick JMcP, Newton A, Martin A, Grace J, Munro RC, Muthoka PN. 1990. Low-technology techniques for the vegetative propagation of tropical trees. Commonw For Rev 69: 247-257.

López-Barrera F, Newton A. 2005. Edge type effect on germination of oak tree species in the Highlands of Chiapas, Mexico. For Ecol Manag 217: 67-79.

Mansoory M. 1992. A Directory of Wetland in Middle Est. Ramsar Sites Information Service, Wageningen.

Newton AC, Mesén JF, Dick McP, Leakey RRB. 1992. Lowtechnology propagation of tropical trees: rooting physiology and its practical implications. In: Mass production Technology for genetically Improved Fast Growing Forest Tree Species. Vol. 2, AFOCEL/IRFRO Burdeos, 1992 Sep 14-18, France. AFOCEL, Nangis, pp 417-424.

Ofori DA, Newton AC, Leakey RRB, Grace J. 1996. Vegetative propagation of Milicia excelsa by leafy stem cuttings: effects of auxin concentrations, leaf areas and rooting medium. For Ecol Manag 84: 39-48.

Qian YL, Engelke MC. 1999. Influence of trinexapac-ethyl on diamond zoysiagrass in a shade environment. Crop Sci. 39: 202-208.

Ramazani M, Taghvaei M, Masaoudi M, Riahi A, Bahbahani N. 2009. The evaluation of drought and salinity effects on germination and seedling growth caper (Capparis spinosa L.). Iran J Rangeland 2: 411-420.
Ray GJ, Brown BJ. 1995. Restoring Caribbean dry forests: evaluation of tree propagation techniques. Restor Ecol 3: 86-94.

Rincón E, Huante P. 1993. Growth responses of tropical deciduous tree seedlings to contrasting light conditions. Trees 7: 202-207.

Rodríguez-Calcerrada J, Pardos JA, Gil L, Aranda I. 2008. Ability to avoid drought stress in seedlings of two oak species is lower in a dense forest understory than in a medium canopy gap. For Ecol Manag 255: 421-430.

Sadeghian T, Taghvaei M, Kharati KM, Falah SSR, Masoudi M, Riahi A. 2010. An investigation of some soil physicochemical properties in Calotropis procera L. habitats (the case study of southern rangelands of Fars province). Rangeland 3: 641-651.

Taghvaei M. 2010. Effects of seed sources and shade on vigor of Brant's oak seedling. J Ecol Field Biol 33: 299-306.

Taghvaei M, Kaef N, Sadeghi H. 2012. The effects of salt stress and prime on germination improvement and seedling growth of Calotropis procera L. seeds. J Ecol Field Biol 35: 73-78.

Tobe K, Li X, Omasa K. 2000. Seed germination and radicle growth of a halophyte, Kalidium capsicum (Chenopodiaceae). Ann Bot 85: 391-396.

Wilson SB, Stoffella PJ. 2006. Using compost for container production of ornamental wetland and flatwood species native to Florida. Nativ Plants J 7: 293-300.

Yusef Saleh SA. 2011. Effect of mixing date palm leaves compost (DPLC) with vermiculite, perlite, sand and clay on vegetative growth of Dahlia (Dahlia pinnata), Marigold (Tagetes erecta), Zinnia (Zinnia elegans) and Cosmos (Cosmos bipinnatus) plants. Res J Environ Sci 5: 655-665. 